\title{
PENDEKATAN SOSIOLOGI HUKUM DALAM MEMAHAMI KONFLIK PERATURAN PERUNDANG-UNDANGAN DI INDONESIA
}

\author{
Rizal Irvan Amin \\ Pascasarjana Fakultas Hukum Universitas Sebelas Maret \\ E-mail: rizalirvanamin@gmail.com
}

\begin{abstract}
The issue of regulation has indeed become a lively discourse in recent years. Laws and regulations, which in essence is a set of regulatory systems to provide an orderly legal order and society, often creates conflicts, both internal conflicts between regulations and external conflicts involving government agencies and the community. The study of legal science in the perspective of sociological jurisprudence is a scientific instrument that makes sense to analyze the phenomenon of legal problems that occur in indonesia, this is because the beginning and the end of a regulation is society. The results show that regulatory conflicts occur because in practice the formation of laws and regulations often ignores procedural due process of law and substantive due process of law, one of the main points is that the widest possible public participation is required in the regulatory formation process. As a result, several regulations that have been produced often cause conflicts due to a mismatch between the substance of the regulations and the conditions and needs of the community.
\end{abstract}

Keywords: Sociological Jurisprudence, Conflict, Laws and Regulations, Indonesia

\begin{abstract}
Abstrak
Isu permasalahan regulasi menjadi diskursus yang sering mencuat beberapa tahun terakhir. Peraturan perundang-undangan yang esensinya merupakan sekumpulan sistem aturan untuk menghadirkan tatanan hukum dan masyarakat yang tertib, justru realitanya sering kali memunculkan konflik, baik konflik internal antar peraturan maupun konflik eksternal yang melibatkan lembaga pemerintahan dan masyarakat. Kajian ilmu hukum dalam perspektif sosiologi hukum menjadi instrumen keilmuan yang masuk akal untuk membedah fenomena permasalahan peraturan perundang-undangan yang terjadi, hal ini dikarenakan hulu dan hilir suatu regulasi adalah masyarakat. Hasil penelitian menunjukkan bahwa konflik regulasi terjadi dikarenakan di dalam praktik pembentukan peraturan perundang-undangan masih sering kali mengabaikan procedural due process of law dan substantive due process of law yang salah satu poin utamanya adalah dibutuhkan partisipasi publik yang seluas-luasnya di dalam proses pembentukan peraturan. Alhasil beberapa regulasi yang dihasilkan kerap menimbulkan konflik dikarenkan ketidaksesuaian antara substansi peraturan dengan keadaan dan kebutuhan di masyarakat.
\end{abstract}

Kata Kunci: Sosiologi Hukum, Konflik, Peraturan Perundang-Undangan, Indonesia

\section{A. Pendahuluan}

Pada 2 November 2020, Pemerintah dan Dewan Perwakilan Rakyat Republik Indonesia (DPR RI) telah resmi mengundangkan UU No. 11 Tahun 2020 tentang Cipta Kerja. Pengundangan ini dilakukan meskipun sebelumnya selama proses pembahasan hingga pengundangan banyak sekali pro dan kontra yang mengiringi UU Ciptaker. Hingga 
puncaknya beberapa kali masyarakat sempat melakukan aksi demonstrasi untuk mengkritik bahkan menolak pengesahan UU tersebut sekalipun ditengah-tengah situasi pandemi Covid-19 yang semakin kritis.

Menilik waktu yang lalu, demonstrasi besar juga pernah dilakukan segenap elemen masyarakat pada 19 September 2019, dimana agendanya untuk menolak pengesahan Rancangan Undang-Undang Kitab Undang-Undang Hukum Pidana (RUU KUHP) dan revisi Undang-Undang Komisi Pemberantasan Korupsi (UU KPK). Sejarah juga mencatat semenjak masa reformasi pada tahun 1998 hingga saat ini, sudah beberapa kali demonstrasi dilakukan oleh masyarakat menyuarakan kritikan dan penolakan terhadap beberapa isu peraturan perundang-undangan di Indonesia.

Menurut Menteri Hukum dan Hak Asasi Manusia (Menkumham), Yasona H. Laoly, peraturanperundang-undangan diIndonesiamasihmenimbulkanbanyak persoalan. Persoalan tersebut seperti misalnya banyak regulasi-regulasi yang overlapping, multipemahaman atau menimbulkan banyak tafsir, hilangnya kesinkronan dan keharmonisan antara peraturan perundang-undangan di tingkat pusat dan daerah, serta peraturan perundang-undangan yang tidak mencakup aspek sosiologis sehingga keberadaanya menjadi tidak efektif. ${ }^{1}$ Persoalanpersoalan tersebut yang selanjutnya menjadikan keadaan peraturan perundang-undangan di Indonesia berada pada spesifikasi kualitas yang rendah (low quality regulation). ${ }^{2}$

Jika melihat data-data yang ada berkaitan dengan keadaan peraturan perundangundangan di Indonesia, pernyataan Menkumham nampaknya memang benar. Pertama, data perihal proses executive review atau pengujian peraturan perundang-undangan di bawah kewenangan eksekutif secara hierarkis. Seperti yang tercantum pada website resmi Kemendagri, ada 3.143 regulasi di level daerah dan peraturan menteri dalam negeri (permendagri) yang diuji dan hasilnya dicabut atau dibatalkan sebab terbukti secara hukum dan sosiologis mempersulit alur birokrasi dan mengganggu laju pertumbuhan ekonomi di daerah. ${ }^{3}$ Saat ini kekuasaan Pemerintah dalam melakukan executive review telah dicabut oleh Mahkamah Konstitusi (MK) melalui putusan MK No. 137/PUU-XIII?2015. Dengan putusan tersebit mekanisme pengujian dan pembatalan peraturan perundang-undangan di bawah kekuasaan eksekutif hanya tinggal melalui proses judicial review di lembaga kekuasaan kehakiman (MA dan MK). Padahal angka peraturan perundang-undangan di bawah kewenangan eksekutif yang bermasalah bisa saja terus bertambah pesat.

Kedua, data berkaitan dengan proses judicial review atau pengujian dan pembatalan regulasi melalui lembaga pemegang kekuasaan kehakiman (MA dan MK), tercatat sejak eksistensi MK dimulai pada tahun 2003 hingga Desember 2020 terdapat 1.380 (45\%) putusan perkara pengujian undang-undang yang diputus oleh Mahkamah Konstitusi dari total keseluruhan 3.063 perkara. ${ }^{4}$ Angka tersebut lebih rendah dibanding total jumlah perkara pengujian undang-undang yang telah diregristasi oleh MK yaitu sebanyak 1.430

1 Rizal Irvan Amin, Mengurai Permasalahan Peraturan Perundang-Undangan di Indonesia", Jurnal Res Publica, Volume 4 Nomor 2, 2020, hlm. 210.

2 M. Nur Sholikin, "Penataan Kelembagaan untuk Menjalankan Reformasi Regulasi di Indonesia", Jurnal Hukum \& Pasar Modal, Vol. VIII No. 4, 2012, hlm 80.

3 Kemendagri, "Kemendagri Segera Buka Detail 3.143 Pembatalan Perda", 21 Juni 2016, https://www.kemendagri.go.id/ berita/baca/12889/kemendagri-segera-buka-detail-3143-pembatalan-perda, diakses pada 21 Desember 2020.

4 Mahkamah Konstitusi Republik Indonesia, https://mkri.id/index.php?page=web.RekapPUU\&menu=4, diakses pada 21 Desember 2020. 
perkara. Sementara itu, untuk mekanisme judicial review dibawah Mahkamah Agung telah terdapat 1.801 putusan yang dikeluarkan oleh MA berkaitan dengan hak uji materiil. ${ }^{5}$ Ketiga, data penelitian dan survey perihal regulasi-regulasi yang memiliki persoalan sosiologis dalam penerapannya, misalnya hasil penelitian yang dipaparkan oleh Komisi Nasional Hak Asasi manusia Perempuan (2016) yang menemukan 421 produk hukum daerah yang diskriminatif. ${ }^{6}$ Penelitian lain juga pernah dilakukan oleh tersebut dilengkapi dengan kajian yang juga dilakukan oleh lembaga Setara Institute for Democracy and Piece, dimana ditemukan total 176 kebijakan publik daerah yang mempercepat praktik intoleransi, diskriminasi, dan kejahatan selama periode 2017-2019. ${ }^{7}$

Dari beberapa data di atas, dapat disimpulkan bahwa masih banyak permasalahan peraturan perundang-undangan yang melilit Indonesia. Tentunya problem regulasi ini perlu untuk cepat ditangani supaya tidak menghambat jalannya proses negara hukum dan demokrasi yang sedang kita bangun. Namun, yang perlu dilakukan terlebih dahulu ialah menganalisa penyebab terjadinya permasalahan regulasi di Indonesia, supaya dalam menentukan solusi penyelesaian masalah regulasi dapat disusun secara efektif, efisien, dan tepat sasaran. Beberapa kajian yang ada, telah menganalisis penyebab konflik peraturan perundang-undangan ini melalui perspektif normatif dan kelembagaan. Secara normatif berarti dilihat penyebab regulasi melalui pandangan ilmu hukum dalam kaidah dan norma pembentukan peraturan perundang-undangan yang benar, sementara sisi kelembagaan melihat masalah regulasi dari perspektif pembagian kewenangan lembaga negara dalam hal pembentukan peraturan perundang-undangan. Padahal selain dapat dikaji dari kedua perspektif tersebut, penyebab permasalahan regulasi juga dapat dianalisa menggunakan pendekatan sosiologi hukum. Hal itu dikarenakan pada esensinya pembentukan peraturan perundang-undangan merupakan serangkaian kegiatan legislasi sebagai menifestasi bentuk komunikasi antara pemerintah (pemegang kekuasaan legislatif) dengan masyarakatnya. ${ }^{8}$ Sehingga hulu dan hilir pembentukan regulasi kembali kepada kepentingan masyarakat secara luas.

Oleh karena itu, Penulis tertarik untuk mengkaji lebih dalam penyebab konflik peraturan perundang-undangan dalam pandangan sosiologi hukum. Dalam hal ini, sosiologi hukum digunakan sebagai instrumen keilmuan yang masuk akal dalam membedah konflik regulasi di Indonesia dikarenakan ilmu ini merupakan cabang kajian dari ilmu hukum yang mempelajari hubungan timbal balik antara proses hukum (pembuatan, penafsiran, maupun pelaksanaan) dengan gejala-gejala dan fakta-fakta sosial yang terjadi di masyarakat. Sehingga diharapkan mampu melihat masalah regulasi yang terjadi di luar perspektif normatif dan kelembagaan.

Agar sistematis, dalam tulisan ini akan terdiri dari 3 pokok kajian, yaitu 1). Berkaitan dengan sosiologi peraturan perundang-undangan; 2). Sosiologi hukum dan pandangannya

5 Direktori Putusan Mahkamah Agung, https://putusan3.mahkamahagung.go.id/search.html?q=\%22Hak+uji + materiil $\% 22 \&$ page $=29$, diakses pada 21 Desember 2020 .

6 Komnas Perempuan, "Laporan Independen Lembaga Nasional Hak Asasi Manusia”, laporan disampaikan kepada Commission on the Status of Women, pada 27 September 2019, hlm. 13.

7 SETARA Institute for Democracy and Peace, "Dampak Produk Hukum Daerah Diskriminatif Terhadap Akses Pelayanan Publik”, $\quad$ https://setara-institute.org/dampak-produk-hukum-daerah-diskriminatif-terhadap-akses-pelayanan-publik/, diakses pada 28 Desember 2020.

8 Pierre Andre Cotte, The Interpretation of Legislation in Canada, Quebeec:Les Edition Yvon Balais, 1991, hlm. 4. 
terhadap konflik peraturan perundang-undangan; dan 3). Urgensitas pembuat regulasi berkarakter hukum dan konstitusi.

\section{B. Pembahasan}

\section{Sosiologi Peraturan Perundang-Undangan}

Peraturan perundang-undangan dalam konteks negara hukum memiliki kedudukan yang penting dan eklusif dikarenakan disetiap elemen kehidupan bernegara, bermasyarakat, berbangsa, bahkan pemerintahan haruslah didasarkan kepada peraturan perundang-undangan. ${ }^{9}$ Peraturan perundang-undangan dalam segala aspek dan sisinya mencirikan asas legalitas dimana harus dipatuhi dan tak boleh disimpangi. Menurut Jalaludin, peranan peraturan perundang-undangan adalah untuk menata dan mengatur kehidupan, mendiseminasikan kepastian hukum, kebermanfaatan, dan keadilan, serta menindak dan memberantas tindak pidana (kejahatan dan pelanggaran). ${ }^{10}$ Dalam keberlangsungannya di negara hukum modern, hukum bukan hanya berkedudukan sebagai instrumen pengendalian sosial (law is a social control), namun juga berfungsi sebagai alat untuk mengarahkan masyarakat secara luas kepada perubahan yang diinginkan (law is a social enginering). ${ }^{11}$ Artinya hukum menjadi instrumen yang menentukan kemajuan, keadaban serta kesejahteraan negara. ${ }^{12}$

Peraturan perundang-undangan dalam pembuatan dan penerapannya merupakan suatu hal yang bersifat multidimensional. Dalam hal ini, yang berperan di dalamnya bukan hanya ilmu hukum murni (perancangan peraturan perundang-undangan) saja, tetapi juga melibatkan pandangan-pandangan turunan ilmu hukum lainnya ataupun juga ilmu dan teori dari rumpun ilmu selain hukum yang harus diperhatikkan, antara lain yaitu antropologi hukum, sosiologi hukum, dan lain sebagainnya. Hal tersebut dikarenakan ilmu hukum, khususnya perancangan peraturan perundang-undangan, hanya berfokus kepada aspek bagaimana cara-cara membentuk suatu regulasi yang baik dan benar sesuai dengan aspek-apek yuridis-normatif pembentukan hukum. Ilmu hukum belum meng-cover aspek-aspek sosial lainnya yang juga perlu diakomodir di dalam pembentukan dan penerapan regulasi. Padahal menurut Bagir Manan, supaya dalam pembentukan suatu peraturan perundang-undangan dapat menghasilkan output regulasi yang baik dan berkualitas, maka haruslah mendasarkan kepada 3 (tiga) aspek, yaitu aspek yuridis (juridische gelding), aspek sosiologis (sociologische gelding), dan aspek filosofis (philosophical gelding). ${ }^{13}$

Hal tersebut sejalan dengan salah satu asas pembentukan peraturan perundangundangan yang baik, seperti yang diatur pada Pasal 5 huruf d UU No. 11 Tahun 2012 jo UU No. 15 Tahun 2019 tentang Pembentukan Peraturan Perundang-Undangan (untuk selanjutnya disebut UU Pembentukan Peraturan Perundang-Undangan) yaitu

9 Jimly Asshiddiqie, Perihal Undang-Undang, Jakarta: Rajawali Press, 2011, hlm. 180.

10 Jalaludin, "Hakikat dan Fungsi Peraturan Perundang-Undangan Sebagai Batu Uji Kritis Terhadap Gagasan Pembentukan Perda yang Baik", Jurnal Aktualita, Volume 6. Nomor 3, 2011, hlm. 2.

11 Rizal Irvan Amin, Op.cit, hlm. 206.

12 Agus Riwanto, “Mewujukan Hukum Berkeadilan Secara Progresif Perspektif Pancasila”, Jurnal Al-Ahkam, Volume 2. Nomor 2, 2017, hlm. 137.

13 Bagir Manan, Dasar-Dasar konstitusional Peraturan Perundang-Undangan Nasional, Padang: Fakultas Hukum Universitas Andalas, 1994, hlm. 13-21. 
asas dapat dilaksanakan. Dengan adanya asas ini maka menegaskan bahwa setiap peraturan perundang-undangan yang ingin dibentuk nantinya harus sesuai dengan keadaan masyarakat sehingga efektif untuk dilaksanakan, kesesuaian yang dimaksud ialah sesuai secara filosofis, yuridis, dan sosiologis. ${ }^{14}$ Aspek filosofis merujuk kepada regulasi tersebut tidak bertentangan dengan nilai dan kaidah hukum tertinggi, yaitu Pancasila dan Undang-Undang Dasar 1945. Aspek yuridis yaitu berarti dalam proses pembentukannya sesuai atau berdasarkan kepada regulasi yang lebih tinggi hierarkinya dan pembentukannya sesuai dengan prosedur yang sudah ditentukan. Artinya regulasi tersebut tidak bertentangan dengan aturan yang lain dan sah secara formil pembuatannya. Sedangkan aspek sosiologis artinya suatu regulasi haruslah dapat dipaksakan keberlakuannya oleh entitas yang berkuasa atau dapat diterima dan diakui oleh masyarakat. Secara sosiologis juga dapat berarti substansi suatu regulasi haruslah sesuai dengan kondisi, keadaan, dan kebutuhan hukum di masyarakat.

Pengaplikasian 3 (tiga) aspek ini di dalam proses pembentukan peraturan perundang-undangan yang baik dapat dikatakan masuk akal. Adanya aspek filosofis memperhitungkan bahwa esensinya hukum merupakan salah satu instrumen untuk mencapai tujuan dan cita-cita suatu bangsa atau negara. Sedangkan tujuan dan cita-cita tersebut dalam konteks Indonesia termaktub pada Pembukaan Undang-Undang Dasar Negara Republik Indonesia (UUD NRI) Tahun 1945, yang kemudian juga dijabarkan ke dalam nilai-nilai Pancasila. Adanya aspek yuridis menyesuaikan dengan sistem ketatanegaraan kita yang menurut Pasal 1 ayat (3) UUD NRI 1945 menegaskan bahwa Negara Indonesia adalah negara hukum (rechstaat) dan bukan negara kekuasaan belaka (machstaat), sehingga segala hal haruslah diatur dengan hukum termasuk proses pembentukan peraturan perundang-undangannya. Dalam hal tersebut, Jimly Asshiddiqie mangatakan "the rule of law, and not of man". ${ }^{15}$ Sementara eksistensi aspek sosiologis memperhitungkan bahwa objek dan subjek pengaturan dari sebuah regulasi adalah masyarakat secara luas. Dalam hal itu, Markus Tullius Cicerro mengatakan " $u b i$ societas, ibi ius" atau jika diartikan berarti dimana ada masyarakat, maka disitu pasti ada hukum. ${ }^{16}$ Sedangkan Satjipto Rahardjo dalam teori hukum progresif-nya mengatakan bahwa "hukum haruslah ada untuk kepentingan manusia, bukan sebaliknya manusia untuk melanggengkan eksistensi hukum". ${ }^{17}$

Kajian sosiologi hukum erat kaitannya dengan aspek sosiologis peraturan perundang-undangan. Menurut Jufrina Rizal, mengatakan bahwa salah satu sub kajian dari sosiologi hukum modern adalah kajian mengenai sosiologi peraturan perundang-undangan atau sosiologi pembuatan undang-undang. ${ }^{18}$ Lebih lanjut dikatakan instrumen keilmuan ini dalam penerapannya dapat membantu untuk mengukur tingkat kemampuan suatu peraturan perundang-undangan beserta melihat

14 Penjelasan Pasal 5 Huruf d UU Pembentukan Peraturan Perundang-Undangan.

15 Jimly Asshiddiqie, "Struktur Ketatanegaraan Republik Indonesia Pasca Perubahan UUD 1945", makalah disampaikan dalam Seminar Pembangunan Hukum Nasional VIII, diselenggarakan oleh Badan Pembinaan Hukum Nasional, Pada hari Senin, 14 Juli 2003, hlm. 3-4.

16 Hendrikus Otniel Nasozaro, "Peranan Hukum dalam Kehidupan Berdemokrasi di Indonesia". Jurnal Warta, Edisi 58, 2018.

17 Marilang, “Menimbang paradigma Keadilan Hukum Progresif”, Jurnal Konstitusi, Vol. 14 No. 2, 2017, hlm. 315.

18 Jufrina Rizal, "Sosiologi Perundang-Undangan dan Pemanfaatannya", Jurnal Hukum dan Pembangunan, No. 3, 2003, hlm. 418. 
bagaimana hubungan antara peraturan perundang-undangan dengan masyarakat yang keduanya bersifat resiprokal. ${ }^{19}$ Kemampuan peraturan perundang-undangan berarti berbicara perihal substansinya apakah mampu memberikan kegunaan dan kekuatan untuk menyelesaikan permasalahan hukum di masyarakat, menciptakan keadilan, serta kepastian hukum. Sedangkan hubungan resiprokal antara hukum dan masyarakat memperlajari bagaimana suatu regulasi bekerja di masyarakat, pun demikian bagaimana masyarakat mempengaruhi pembentukan suatu peraturan perundang-undangan.

Sosiologi peraturan perundang-undangan pada esensinya bekerja untuk membuat suatu antisipasi terhadap kesenjangan antara hukum dengan masyarakat yang selalu berkembang. Keberadaan sosiologi hukum dalam pembentukan peraturan sangatlah penting karena sosiologi hukum membantu pembuat regulasi dalam melihat perubahanperubahan dinamis suatu regulasi, hubungan antara kepentingan masyarakat dengan regulasi, hingga hubungan antara regulasi dengan sistem nilai yang hidup dan berkembang di masyarakat. Dalam perspektif sosilogi hukum, seperti yang dikatakan oleh Satjipto Rahardjo dalam bukunya "sosiologi hukum, perkembangan, metode dan pilihan masalahnya" mengungkapkan bahwa proses pembuatan peraturan tidak bisa dipandang sebagai sebuah pekerjaan yang netral dan independen. Setiap peraturan perundang-undangan pastilah bermula dari sebah fenomena sosial, memiliki suatu tujuan sosial, mengandung unsur intervensi sosial, dan memiliki dampak sosial. ${ }^{20}$

Eugen Ehrich berpendapat titik berat perkembangan hukum bukanlah terdapat pada peraturan perundang-undangan, putusan hakim, dan ilmu hukum. Akan tetapi hukum lahir dan berkembang dari masyarakat. ${ }^{21}$ Sehingga peraturan perundang-undangan, putusan hakim, dan ilmu hukum patutlah berpijak kepada fakta, gejala, dan masalah yang terjadi di masyarakat. Pun demikian dengan tujuan pembentukan suatu regulasi haruslah didedikasikan kepada kepentingan dan keadilan masyarakat luas. Sebagaimana yang dikatakan oleh Jeremy Bentham bahwa hukum / peraturan perundang-undangan dibentuk untuk sebesar-besarnya kebahagiaan masyarakat secara menyeluruh. ${ }^{22}$

Pada dasarnya, konsep peraturan perundang-undangan yang baik dalam pandangan sosiologi hukum ialah peraturan yang lebih menekankan kepada "kenyataan hukum" dari pada posisi dan fungsi regulasi di masyarakat. ${ }^{23}$ Peraturan perundang-undangan selayaknya didudukan sebagai sebuah kemauan publik, sehingga tidak hanya mementingkan aspek "law in the books"-nya saja tetapi juga regulasi tersebut harus selaras dengan aspek "law in action". Sosiologi peraturan perundang-undangan membantu menunjukkan titik temu diantara keduannya, dimana peran strategis dari peraturan perundang-undangan tidak selalu dipandang sebagai instrumen untuk mengontrol masyarakat (law is a tool of social control) yang lebih bersifat formalistik dan mementingkan aspek yuridis-normatif. Sosiologi peraturan perundang-undangan melihat peran strategis sebuah regulasi adalah juga sebagai instrumen untuk membawa

19 Ibid.

20 Satjipto Rahardjo, Sosiologi Hukum, Perkembangan, Metode dan Pilihan Masalahnya, Surakarta:Muhammadiyah University Press, 2002.

21 Soemanto, Hukum dan Sosiologi Hukum: Pemikiran, Teori, dan Masalah, Surakarta:UNS Press, 2008, hlm. 10.

22 Jeremy Bentham, Theory of Legislation, London:Trubner \& CO, 1979.

23 Marsudi Dedi Putra, "Kontribusi Aliran Sociological Jurisprudence Terhadap Pembangunan Sistem Hukum Indonesia", Jurnal Ilmiah Fakultas Keguruan dan Ilmu Pendidikan, Vol. 16 No. 2, hlm. 50. 
perubahan positif menuju apa yang dikehendaki. Perubahan yang sesuai dengan nilainilai yang lahir dan hidup di masyarakat serta sesuai dengan tujuan dan cita-cita bangsa. Dalam hal itu, Roscoe Pound mengatakan bahwa "law is a tool of social engineering".

Oleh karena itu, dapat disimpulkan bahwa perspektif sosiologi peraturan perundang-undangan sangatlah dibutuhkan di dalam proses pembentukan regulasi. Melalui perspektif ini para pembuat peraturan perundang-undangan dibantu untuk dapat masuk melihat kondisi, keadaan, dan kebutuhan hukum di masyarakat yang pada hakikatnya bersifat dinamis atau terus mengalami perbahan-perubahan. Pendekatan sosiologi peraturan perundang-undangan dibutuhkan untuk memenuhi salah satu syarat aspek penting yang harus dipenuhi bagi suatu peraturan perundang-undangan yang baik, yaitu aspek sosiologis (sociologische gelding).

\section{Sosiologi Hukum dan Konflik Peraturan Perundang-Undangan}

Pembentukan peraturan perundang-undangan sejak proses awal pembentukannya yakni perencanaan sudah dituntut supaya produk hukum yang dihasilkan nantinya mampu memenuhi kebutuhan masyarakat diberbagai aspek dan mampu menyelesaiakan permasalahan hukum yang ada. Pertama, dapat dilaksanakan; kedua, mampu ditegakkan; ketiga, sejalan dengan asas dan teori pembentukan peraturan perundangan; dan keempat, selaras dengan aspirasi masyarakat. ${ }^{24}$ Keadaan ini menunjukan bahwa pembentukan peraturan perundang-undangan bukan hanya sebatas kegiatan formalitas biasa, namun juga secara substansi dan prosedural harus berdasarkan asas-asas pembentukan peraturan perundang-undangan yang baik sehingga dapat tercipta regulasi yang berkualitas.

Esensinya dalam sebuah negara, utamanya negara hukum yang demokratis, pembentukan peraturan perundang-undangan haruslah merujuk kepada pedomanpedoman pembentukan peraturan yang dituangkan dalam bentuk undang-undang. Konteks Indonesia, pedoman pembentukan tersebut diatur melalui UU Pembentukan Peraturan Perundang-Undangan yang di dalamnya diatur berbagai hal berkaitan dengan penyusunan peraturan perundang-undangan mulai dari tingkat undang-undang hingga peraturan daerah. Pada Pasal 5 dan Pasal 6, diatur mengenai asas pembentukan peraturan perundang-undangan. Dengan ketentuan ini, mewajibkan para pembentuk peraturan untuk merujuk dan sekaligus menyematkan asas-asas itu dalam setiap peraturan perundang-undangan yang dibuat. Tujuannya ialah supaya hukum yang dihasilkan ialah hukum yang baik dan berkualitas sehingga mampu menyelesaikan permasalahan yang timbul di masyarakat serta menghadirkan perlindungan dan pengayoman kepada rakyat sebagai objek yang diatur. Adapun asas-asas yang dimaksud terdiri dari $:^{25}$

a. Asas kejelasan tujuan, bahwa pada tiap-tiap pembentukan peraturan perundangundangan didalamnya harus memuat tujuan apa yang ingin dituju secara jelas. Tujuan tersebut haruslah sudah dimunculkan secara jelas dari proses awal yaitu perencanaan dan penyusunan. Dalam hal tersebut, penyusunan naskah akademik menjadi sarana untuk menjelaskan tujuan pembentukan pada tahapan perencanaan, sedangkan pada proses penyusunan, aspek tujuan yang jelas harus dituangkan dalam konsideran penimbang yang terdiri dari landasar filosofis, yuridis, dan sosiologis;

24 A. Ahsin Thohari, “Reorientasi Fungsi Legislasi Dewan Perwakilan: Upaya Menuju Undang-Undang Responsif”, Jurnal Legislasi Indonesia, Vol. 8. No. 4, 2011, hlm. 569.

25 Pasal 5 UU Pembentukan Peraturan Perundang-Undangan 
b. Asas kelembagaan atau pejabat pembentuk yang tepat, bahwa peraturan perundang-undangan haruslah dibentuk oleh pihak-pihak yang memang memiliki kewenangan untuk itu. Selain berwenang pihak yang membentuk juga haruslah pihak yang memang berkompeten di bidang tersebut. Asas kelembagaan yang tepat juga berhubungan dengan bagaimana sistem kelembagaan yang dibangun dalam pembentukan dan pengelolaan regulasi. Fungsi pembentukan dan pengelolaan regulasi haruslah diberikan kepada lembaga yang secara filosofis, yuridis, dan sosiologis tepat untuk mewujudkan peraturan perundang-undangan yang berkualitas;

c. Asas kesesuaian antara jenis, hierarki, dan materi muatan, yaitu bahwa peraturan perundang-undangan mestilah disusun dari tingkatan yang tertinggi hingga ke tingkatan terendah. Selain itu, pada prinsipnya regulasi yang lebih rendah haruslah sinkron dan sesuai dengan regulasi yang lebih tinggi;

d. Asas dapat dilaksanakan, bahwa setiap peraturan perundang-undangan yang ingin dibentuk nantinya harus sesuai dengan keadaan masyarakat sehingga efektif untuk dilaksanakan; kesesuaian tersebut ialah sesuai secara filosofis, yuridis, dan sosiologis. Peraturan perundang-undangan haruslah dapat dilaksanakan tidak hanya oleh pemerintah selaku pelaksana, tetapi juga oleh masyarakat secara luas. Sehingga implikasi atau dampak dari pembentukan peraturan perundang-undangan harus diperhitungkan sejak tahap awal penyusunan. Efektifitas yang dimaksud disini juga haruslah efektif secara ekonomi (beban keuangan negara);

e. Asas kedayagunaan dan kehasilgunaan, bahwa peraturan perundang-undangan yang dibentuk haruslah dapat menyelesaikan permasalahan masyarakat di berbagai aspek. Asas ini secara tujuan berkaitan dengan "asas dapat dilaksanakan";

f. Asas kejelasan rumusan, yaitu bahwa peraturan perundang-undangan yang dibentuk harus memenuhi persyaratan teknis dan sistematika penyusunan peraturan perundang-undangan. Perlu diperhatikan terkait dengan pemilihan kata dan istilah serta bahasa hukum yang jelas supaya peraturan tersebut dapat dipahami oleh masyarakat. Jangan sampai suatu peraturan perundang-undangan menimbulkan multitafsir sehingga tidak menciptakan kepastian hukum; dan

g. Asas keterbukaan, bahwa peraturan perundang-undangan dalam proses pembentukannya haruslah melibatkan peran aktif masyarakat.

Ketujuh asas tersebut bersifat kumulatif, artinya kesemuanya haruslah ditaati dan dipenuhi dalam setiap pembentukan peraturan perundang-undangan. Jika suatu peraturan perundang-undangan tidak memenuhi asas-asas tersebut maka konsekwensi yang timbul adalah suatu peraturan dapat dibatalkan atau batal demi hukum. selain asas-asas pembentukan peraturan perundang-undangan yang baik, asas lain yang harus menjadi pedoman adalah asas terkait materi muatan yang diatur dalam peraturan perundangundangan, yaitu: Asas Ketuhanan yang Maha Esa, pengayoman, kemanusiaan, kebangsaan, kekeluargaan, kenusantaraan, Bhinneka Tunggal Ika, keadilan, kesamaan kedudukan di depan hukum dan pemerintahan, ketertiban dan kepastian hukum, dan keseimbangan. 
Asas-asas yang terkandung di dalam Pasal 5 dan Pasal 6 UU Pembentukan Peraturan Perundang-Undangan mewakili 3 (tiga) syarat aspek yang harus dipertimbangkan dan dipenuhi dalam proses pembentukan regulasi yaitu aspek filosofis, yuridis dan sosiologis. Bahkan empat dari tujuh asas pada Pasal 5 berisikan aspek sosiologis peraturan perundang-undangan. Hal ini menunjukkan bahwa aspek sosiologis lebih terasa utama dibanding dua aspek lainnya, yaitu yuridis dan filosofis. Berkaitan dengan itu, Marc Tullius Cicero pernah mengutarakan sebuah adagium dalam bukunya " $D e$ Legibus" bahwa kesejahteraan, kebahagiaan, dan keselamatan rakyat haruslah menjadi hukum tertinggi (salus populi suprema lex). Dalam konteks Indonesia, adagium tersebut sebenarnya sejalan dengan amanat konstitusi negara seperti yang tercantum pada bagian Pembukaan UUD NRI 1945 alinea keempat yang menegaskan bahwa melindungi segenap bangsa Indonesia dan seluruh tumpah darah Indonesia, memajukkan kesejahteraan umum, mencerdaskan kehidupan bangsa, dan ikut melaksanakan ketertiban dunia yang berdasarkan kemerdekaan, perdamaian abadi, dan keadilan sosial merupakan tujuan dan cita-cita dibentuknya Pemerintahan Negara Indonesia. Lebih lanjut konstitusi negara dalam Pasal 1 ayat (2) UUD NRI 1945 mengatur bahwa kedaulatan berada di tangan rakyat dan dilaksanakan menurut UUD. Dengan begitu, sepatutnya aspek sosiologis sebagai aspek yang langsung bertalian dengan bagaimana keadaan, kondisi, dan kebutuhan masyarakat haruslah lebih diutamakan dari pada sekedar mengejar aspek formalistik suatu peraturan perundang-undangan. Meskipun kalau merujuk kepada proses pembuatan regulasi yang baik dan benar baik aspek sosiologis, yuridis, dan filosofis semuanya wajib dipenuhi secara bersamaan.

Sebenarnya di dalam UU Pembentukan Peraturan Perundang-Undangan telah diatur mekanisme-mekanisme pembentukan regulasi (procedural process of law) supaya mampu menampung aspek sosiologis peraturan. Mekanisme ini diatur di dalam Bab XI Pasal 96 tentang Partisipasi Masyarakat, secara lengkapnya Pasal ini berbunyi:

1) Masyarakat berhak memberikan masukan secara lisan dan/atau tertulis dalam Pembentukan Peraturan Perundang-Undangan.

2) Masukan secara lisan dan/atau tertulis sebagaimana dimaksud pada ayat (1) dapat dilakukan melalui:
a. Rapat dengar pendapat umum;
b. Kunjungan kerja;
c. Sosialisasi; dan/atau
d. Seminar, lokakarya, dan/atau diskusi.

3) Masyarakat sebagaimana dimaksud pada ayat (1) adalah orang perseorangan atau kelompok orang yang mempunyai kepentingan atau substansi Rancangan Peraturan Perundang-Undangan.

4) Untuk memudahkan masyarakat dalam memberikan masukan secara lisan dan/ atau tertulis sebagaimana dimaksud pada ayat (1), setiap Rancangan Peraturan Perundang-Undangan harus dapat diakses dengan mudah oleh masyarakat.

Dengan Pasal tersebut merepresentasikan empat asas pembentukan peraturan perundang-undangan yang baik secara sosiologis sebagaimana diatur pada Pasal 5 
UU Pembentukan Peraturan Perundang-Undangan, yaitu asas kejelasan tujuan, dapat dilaksanakan, kedayagunaan dan kehasilgunaan, serta keterbukaan. Idealnya apabila suatu peraturan perundang-undangan dalam pembentukannya telah sesuai dengan asasasas pembentukan peraturan yang baik dan benar, maka ia akan mampu bekerja dan diterima oleh masyarakat. Akan tetapi sebaliknya, apabila pengesahan dan penerbitan suatu peraturan mendapatkan respon negatif dari masyarakat, berarti terdapat permasalahan di dalam proses pembentukan maupun isi substansi dari peraturan perundang-undangan yang mungkin saja belum melewati proses pembentukan peraturan perundang-undangan yang sudah diatur di dalam UU Pembentukan Peraturan Perundang-Undangan, baik itu mengacu kepada procedural due of law maupun substantive due process of law.

Sebagai contoh konkret dapat dilihat dari UU Ciptaker yang tempo hari baru diundangkan oleh Pemerintah. Dalam proses pembentukan hingga isi substansi UU Ciptaker dirasa menyimpangi beberapa asas pembentukan peraturan perundangundangan yang baik. Sebagai hasilnya regulasi yang dimunculkan juga memiliki kualitas yang rendah, dimana tidak mencirikan kehendak, keadaan, dan kebutuhan masyarakat. Sehingga banyak elemen masyarakat melakukan demonstrasi untuk mekngkritik dan menolak UU Ciptaker. Secara proses / mekanisme pembuatan regulasi, UU Ciptaker dapat dianggap cacat formil. Menurut pakar hukum tata negara, Agus Riwanto, menyampaikan bahwa penyusunan UU Ciptaker tidak memperlihatkan sifat teknokratik pembentukan regulasi yang kemudian menyebabkannya terasa tidak lazim, maka berpotensi cacat secara formil. ${ }^{26}$

UU Ciptaker dalam pembentukannya juga dirasa jauh dari amanat Pasal 96 UU Pembentukan Peraturan Perundang-Undangan yang terlihat dari sejak awal proses perencanaan hingga pengundangan dirasa tidak partisipatif. Hal tersebut ditunjukkan pada proses perencanaan hingga pembahasan, dimana seharusnya draft Rncangan Undang-Undang seharusnya selalu di-update untuk dipublikasikan kepada publik, tetapi realitanya bahkan hingga UU Ciptaker disahkan oleh DPR dan Pemerintah draft UU Ciptaker sering kali tidak update serta muncul versi draft yang berbeda-beda jumlah halaman dan isi materinya. ${ }^{27}$

Oleh karena itu, dalam pandangan sosiologi hukum konflik peraturan perundangundangan, baik internal ataupun eksternal, yang kerap terjadi di Indonesia disebabkan oleh masih belum dipenuhi atau bahkan masih disimpanginya aspek sosiologis dalam pembentukan suatu regulasi. Suatu regulasi yang bermasalah pasti dalam tata cara pembuatan ataupun isi substansinya masih belum menjadikan keadaan, kondisi, dan kebutuhan masyarakat sebagai fokus utamanya, sebaliknya regulasi tersebut biasanya menjadikan tujuan dari individu atau kelompok tertentu sebagai pihak yang akan diuntungkan. Sehingga, dalam eksistensinya sebagai peraturan perundang-undangan di Indonesia banyak mengalami kritikan bahkan penolakan dari kalangan masyarakat secara luas.

26 Agus Riwanto, "Menguak Cacat Formil UU Cipta Kerja", 13 Oktober 2020, https://www.hukumonline.com/berita/baca/ 1t5f854ded1a0b5/menguak-cacat-formil-uu-cipta-kerja-oleh--agus-riewanto/, diakses pada 28 Desember 20202020.

27 Rizal Irvan Amin, Riska Ulfasari Dewi, Tegar Satrio.W, “Omnibus Law Antara Desiderata dan Realita (Sebuah kajian Legislative Intent)”, Jurnal Samudra Keadilan, Vol. 15 No. 2, 2020, hlm. 204-205. 


\section{Urgensitas Pembuat Regulasi Berkarakter Hukum \& Konstitusi}

UU No. 12 Tahun 2011 jo UU No. 15 Tahun 2019 tentang Pembentukan Peraturan Perundang-Undangan sebenarnya telah secara detail dan rigid mengatur perihal tata cara pembentukan peraturan perundang-undangan, baik mulai dari tingkat undangundang hingga peraturan daerah. UU Pembentukan Peraturan Perundang-Undangan telah memberikan pedoman yang jelas dan tegas kepada para pembuat regulasi tentang bagaimana mekanisme membentuk peraturan yang baik secara filosofis, yuridis, dan sosiologis.

Pada bagian sebelumnya sudah disebutkan bahwa terdapat ketentuan pada Pasal 5, Pasal 6, dan Pasal 96 UU Pembentukan Peraturan Perundang-Undangan yang menjadi landasan yuridis mengikat bagi para pembuat regulasi supaya memperhatikan dengan seksama partisipasi publik dalam pembentukan regulasi, mulai dari tahap perencanaan hingga pengundangan dan bahkan pelaksanaan regulasi. Pun demikian juga berkaitan dengan aspek filosofis, UUD NRI 1945 dan Pancasila sudah secara tegas dan apik memberikan penekanan-penekanan kepada tujuan, cita-cita, serta nilai yang kita pegang dan usahakan untuk dicapai di dalam kehidupan berbangsa, bernegara, dan bermasyarakat. Baik mendasarkan kepada yuridis-normatif maupun yuridiskonstitusional, keduanya telah memberikan arahan yang jelas bahwa aspek filosofis, yuridis, dan sosiologis menjadi poin utama yang harus dipenuhi dalam kaitannya menjalankan dan membangun Negara Kesatuan Republik Indonesia.

Atas dasar itu, sebenarnya permasalahan bukan berada di tataran normatif mengenai aturan yang menjadi pedoman pembuat regulasi dalam membuat peraturan (UU pembentukan Peraturan Perundang-Undangan. Akan tetapi, permasalahan berada pada tataran personal atau orang-orang yang berwenang untuk membentuk regulasi. Apabila pemahamannya terhadap ilmu hukum (perancangan peraturan) dan nilai-nilai yang terdapat dalam konstitusi negara baik, maka pasti regulasi-regulasi yang dihasilkan akan mampu baik pula. Permasalahannya saat ini adalah fungsi pengontrolan dan penjaminan kualitas sumber daya manusia perancang peraturan perundang-undangan sulit sekali untuk dikontrol. Banyak perancang peraturan perundang-undangan di biro hukum tiap-tiap kementrian, lembaga, komisi, atau pemerintah daerah tidak memiliki kualitas yang bagus terkait dengan perancangan peraturan. Menurut Badan Pembinaan Hukum Nasional, para legal drafter yang ada saat ini sebagian besar belum memiliki kapasitas yang memadai dalam memahami kebijakan-kebijakan yang menjadi inti substansi regulasi. Menurutnya para legal drafter belum mampu menggunakan prinsip lex spesialis derogat legi generalis ataupun lex superior derogat legi inferior dengan baik. Para legal drafter juga masih banyak yang belum memahami ilmu hukum dan nilai-nilai konstitusi secara utuh.

Selain bermakna legal drafter yang ada pada setiap kementrian, lembaga, atau pemerintahan daaerah, orang-orang pembuat regulasi juga merujuk kepada para anggota legislatif atau DPR yang notabennya mereka yang memiliki kewenangan untuk membentuk peraturan perundang-undangan di tingkat undang-undang. Permasalahan yang dialami juga serupa bahwa banyak anggota DPR yang tidak memiliki background ilmu hukum. Padahal perancangan peraturan perundang-undangan bukanlah perkara mudah yang bisa dilakukan oleh siapapun. Hal senada juga diutarakan oleh Mahfud 
MD ketika masih menjabat sebagai Ketua MK, bahwa banyak anggota legislatif yang tidak memahami masalah hukum, masalah konstitusi, masalah pemerintahan, dan masalah politik. Lebih lanjut dikatakan alhasil banyak undang-undang yang dihasilkan oleh lembaga legislatif yang berkualitas rendah dicirikan dengan proses maupun susbtansi yang tidak pro kepada rakyat, dan sebaliknya justru sarat akan kepentingankepentingan politik golongan tertentu.

Oleh karena itu, dibutuhkanlah orang-orang yang memiliki pemahaman terhadap hukum (understanding of law) dan yang memiliki karakter konstitusi untuk duduk sebagai legal drafter di setiap kementrian, lembaga, atau pemerintah daerah, maupun wakil rakyat yang ada di lembaga legislatif. Langkah ini diperlukan untuk menaikkan kualitas peraturan perundang-undangan di Indonesia karena bagaimanapun sebaikbaik dan seburuk-buruk peraturan perundang-undangan, ia merupakan hasil buatan dari manusia. Peningkatan kualitas pembuat regulasi akan berjaan linear dengan meningkatnya kualitas regulasi. Sedangkah langkah tersebut dapat ditempuh dengan mengevaluasi jalannya fungsi pengontrolan dan penjaminan kualitas pembuat undangundang. Evaluasi harus dilakukaan sejak tahap perekrutan hingga pembinaan para pembuat regulasi. Di tahap perekrutan harus ditingkatkaan standart penerimaan para pembuat regulasi di setiap kementrian, lembaga, dan pemerintah daerah. Sementara di tahapan pembinaan dilakukan dengan terus memberikan pelatihan-pelatihan kepada para legal drafter berkaitan dengan ilmu hukum, khususnya perancangan peraturan perundang-undangan, dan penanaman terhadap nilai-nilai konstitusi.

\section{Kesimpulan}

Bagian kesimpulan dapat berisi hasil pemikiran/analisis ataupun rekomendasi. Kesimpulan bukan tulisan ulang dari pembahasan dan juga bukan ringkasan, melainkan penjelasan singkat dalam bentuk kalimat utuh atau dalam bentuk butir-butir kesimpulan secara berurutan. Kesimpulan harus menjawab pertanyaan dan rumusan permasalahan. Segitiga konsistensi (masalah-tujuan-kesimpulan) harus dicapai sebagai upaya cek dan ricek.

\section{Daftar Pustaka}

\section{Buku}

Bagir Manan, Dasar-Dasar konstitusional Peraturan Perundang-Undangan Nasional, Padang: Fakultas Hukum Universitas Andalas, 1994.

Jeremy Bentham, Theory of Legislation, London:Trubner \& CO, 1979.

Jimly Asshiddiqie, Perihal Undang-Undang, Jakarta: Rajawali Press, 2011.

Pierre Andre Cotte, The Interpretation of Legislation in Canada, Quebeec:Les Edition Yvon Balais, 1991.

Satjipto Rahardjo, Sosiologi Hukum, Perkembangan, Metode dan Pilihan Masalahnya, Surakarta:Muhammadiyah University Press, 2002. 
Soemanto, Hukum dan Sosiologi Hukum: Pemikiran, Teori, dan Masalah, Surakarta:UNS Press, 2008.

\section{Jurnal dan Artikel}

A. Ahsin Thohari, "Reorientasi Fungsi Legislasi Dewan Perwakilan: Upaya Menuju UndangUndang Responsif”, Jurnal Legislasi Indonesia, Vol. 8. No. 4, 2011.

Agus Riwanto, "Mewujukan Hukum Berkeadilan Secara Progresif Perspektif Pancasila", Jurnal Al-Ahkam, Volume 2. Nomor 2, 2017.

Hendrikus Otniel Nasozaro, "Peranan Hukum dalam Kehidupan Berdemokrasi di Indonesia". Jurnal Warta, Edisi 58, 2018.

Jalaludin, "Hakikat dan Fungsi Peraturan Perundang-Undangan Sebagai Batu Uji Kritis Terhadap Gagasan Pembentukan Perda yang Baik", Jurnal Aktualita, Volume 6. Nomor $3,2011$.

Jimly Asshiddiqie, "Struktur Ketatanegaraan Republik Indonesia Pasca Perubahan UUD 1945”, makalah disampaikan dalam Seminar Pembangunan Hukum Nasional VIII, diselenggarakan oleh Badan Pembinaan Hukum Nasional, Pada hari Senin, 14 Juli 2003.

Jufrina Rizal, "Sosiologi Perundang-Undangan dan Pemanfaatannya", Jurnal Hukum dan Pembangunan, No. 3, 2003.

Komnas Perempuan, "Laporan Independen Lembaga Nasional Hak Asasi Manusia”, laporan disampaikan kepada Commission on the Status of Women, pada 27 September 2019.

Marilang, "Menimbang paradigma Keadilan Hukum Progresif”, Jurnal Konstitusi, Vol. 14 No. 2, 2017.

M. Nur Sholikin, "Penataan Kelembagaan untuk Menjalankan Reformasi Regulasi di Indonesia”, Jurnal Hukum \& Pasar Modal, Vol. VIII No. 4, 2012.

Marsudi Dedi Putra, “Kontribusi Aliran Sociological Jurisprudence Terhadap Pembangunan Sistem Hukum Indonesia", Jurnal Ilmiah Fakultas Keguruan dan Ilmu Pendidikan, Vol. 16 No. 2.

Rizal Irvan Amin, Mengurai Permasalahan Peraturan Perundang-Undangan di Indonesia", Jurnal Res Publica, Volume 4 Nomor 2, 2020.

Rizal Irvan Amin, Riska Ulfasari Dewi, Tegar Satrio.W, “Omnibus Law Antara Desiderata dan Realita (Sebuah kajian Legislative Intent)", Jurnal Samudra Keadilan, Vol. 15 No. 2 , 2020.

\section{Peraturan Perundang-Undangan}

Undang-Undang Dasar Republik Indonesia Tahun 1945

Undang-Undang No. 12 Tahun 2011 tentang Pembentukan Peraturan Perundang-Undangan

Undang-Undang No. 15 tahun 2019 tentang Perubahan Atas Undang-Undang No. 12 Tahun 2011 tentang Pembentukan Peraturan Perundang-Undangan. 
Rizal Irvan Amin. Pendekatan Sosiologi Hukum dalam Memahami Konflik...

\section{Internet}

Agus Riwanto, "Menguak Cacat Formil UU Cipta Kerja", 13 Oktober 2020, https://www. hukumonline.com/berita/baca/lt5f854ded1a0b5/menguak-cacat-formil-uu-cipta-kerjaoleh--agus-riewanto/, diakses pada 28 Desember 20202020.

Direktori Putusan Mahkamah Agung, https://putusan3.mahkamahagung.go.id/search.html?q= $\% 22 \mathrm{Hak}+$ uji + materiil\%22\&page=29, diakses pada 21 Desember 2020 .

Kemendagri, "Kemendagri Segera Buka Detail 3.143 Pembatalan Perda", 21 Juni 2016, https://www.kemendagri.go.id/berita/baca/12889/kemendagri-segera-buka-detail-3143pembatalan-perda, diakses pada 21 Desember 2020.

Mahkamah Konstitusi Republik Indonesia, https://mkri.id/index.php?page=web. RekapPUU\&menu=4, diakses pada 21 Desember 2020.

SETARA Institute for Democracy and Peace, "Dampak Produk Hukum Daerah Diskriminatif Terhadap Akses Pelayanan Publik", https://setara-institute.org/dampak-produk-hukumdaerah-diskriminatif-terhadap-akses-pelayanan-publik/, diakses pada 28 Desember 2020 